2017-09-28

\title{
Roma inclusion post Brexit: a challenge to existing rhetoric?
}

James, Zoe

http://hdl.handle.net/10026.1/9861

10.1108/SC-06-2017-0022

Safer Communities

Emerald

All content in PEARL is protected by copyright law. Author manuscripts are made available in accordance with publisher policies. Please cite only the published version using the details provided on the item record or document. In the absence of an open licence (e.g. Creative Commons), permissions for further reuse of content should be sought from the publisher or author. 
A version of this paper is published in: James, Z. and Smith, D. (2017) Safer Communities. 16, 4: DOI 10.1108/ SC-06-2017-0022

Acceptance date: 10/08/2017, Embargo release 12 months

\title{
Roma Inclusion Post Brexit: A Challenge to Existing Rhetoric?
}

\begin{abstract}
Purpose of this paper: This paper proposes that the UK's exit from the EU is unlikely to impact heavily on the lived reality of Roma, given its negligible impact prior to Brexit. The paper sets out a critique of existing EU approaches to anti-Gypsyism that are based in discourses of racism and anti-nomadism and are typified in the EU hate crime agenda. The paper argues for recognition of the systemic social harms caused by discrimination against Roma in the EU and the commonality of their experience with other socially excluded groups that do not conform to the requirements of contemporary neoliberal capitalism.
\end{abstract}

Design/methodology/approach: The paper comprises an opinion piece that sets out a critical examination of existing literature on policy and research in Romani studies and utilises theoretical work within criminology and social policy.

Findings: The paper explains the inability of existing EU approaches to tackle social harms experienced by Roma throughout the EU. In doing so it suggests that the UKs exit from the EU may not have a significant impact on Roma in the UK.

What is original/value of paper: The paper challenges extant discourses and proposes new ways of thinking about anti-Gypsyism.

\section{Introduction}

This paper is an opinion piece which argues that the EU has had a negligible impact on the lived realities of Roma ${ }^{1}$ in Europe and therefore that Brexit is unlikely to have a significant impact on them either. We suggest that existing narratives and analyses of Roma exclusion fail to appreciate or acknowledge the wider organising social structures of capitalist neoliberalism that places the majority of Roma, along with multiple other marginalised groups, at the bottom of a hierarchy that fortunes the wealthy and privileged few. In doing so, we intend to challenge those popular scholarly narratives for anti-Gypsyism that are located fundamentally in discourses on anti-nomadism and racism. The paper will firstly set out how this existing rhetoric has explained the stigma experienced by Europe's Roma populations. It will then consider how the EU has responded to anti-Gypsyism within that context, particularly

\footnotetext{
${ }^{1}$ We have deliberately chosen to use the over-arching term 'Roma' for the purposes of this paper in order to conform to the agreement at the first World Romani Congress in 1971 to use this moniker. However, we recognise that in the UK many prefer the titles Gypsy or Traveller, rather than Roma, and likewise in mainland Europe the communities are diverse. Liegeois refers to Roma as 'a rich mosaic of ethnic fragments'(1994:12, Kostadinova, 2011).
} 
considering its engagement with the hate crime agenda. Finally, the paper will suggest that the EU response to anti-Gypsyism has largely only served to identify Roma experiences of subjective violence that manifest as hate crime, rather than acknowledging the systemic violence they experience as discrimination. In doing so the EU approach has insufficiently challenged anti-Gypsyism due to its neglect of the structural and systemic origins of this phenomenon.

In order to effectively discuss the failure of the EU to address anti-Gypsyism as a systemic issue, this paper considers the problem from a Europe-wide perspective. In doing so it is then able to set out the potentially negligible impact on Roma communities of the UK's exit from the EU. The paper does not intend to provide a policy analysis, but rather it aims to promote discussion of inequality, the role of the EU and Brexit as it unfolds.

\section{Existing Rhetoric on Anti-Gypsyism}

Since the mid $19^{\text {th }}$ century what was to become known as Romani studies has comprehensively examined the lives and experiences of the Roma (for example: Kenrick and Puxon, 1972; Okely, 1983, Fraser, 1992, Acton, 2010). As part of this work the prejudice and discrimination often shown towards Roma by majority societies has largely been explained in two interrelated ways: as products of antinomadism and racism. We will now briefly set out those perspectives and a critique of them in turn.

In the first, the Roma's nomadic lifestyles have been seen as diametrically opposed to sedentarist principles of modernity that rely on wage labour and fixed residence (Sibley, 1994, Halfacree, 1996). McVeigh (1997:9) defines sedentarism as 'the system of ideas and practices which serve to normalise and reproduce sedentary modes of existence'. This divergence around attitudes to, and practices in relation to, work and land use has resulted in community tensions, social distancing and the stigmatising of nomadic communities. As such, Roma have been described as 'insular' minorities (Ryder, 2011), living 'outside' the modern environment (Karner, 2004).

While this difference in attitudes and practices may explain some animosity and conflict between communities we would argue that it is an insufficient explanation for anti-Gypsyism on its own. To begin with, such explanations tend to be overly focused on the small proportion of Roma that are still mobile communities. Mobility does not equate to nomadism, nor does it denote Roma identity. Roma culture instead values 'the tradition or even potential of nomadism, economic independence and flexibility, different family structure, language and caravan dwelling' (Kabachnik, 2009: 469), rather than specifically mobility. Additionally, even when settled in housing or on permanent sites Roma often continue to be stigmatised by the surrounding population (Smith and Greenfields, 2013). Anti-nomadism as an explanatory framework also conflates mobility with migration (Acton, 2010) and while 
Roma migration may help us to understand aspects of their stigmatisation it does not fully explain it (Acton, 2010; Mawby and Gisby, 2009). This is most obviously because most Roma communities, including those in the UK, have been settled in their home country for centuries. Moreover in the early modern period the Roma were one small element of a much larger peripatetic population with social mixing between different sections of the population. Consequently many modern-day Gypsies and Travellers in the UK for example are of indigenous, not ethnic-Roma, origins (Beier, 1985; Mayall, 1988). Finally the notion of Roma living 'outside' of the economic and social structures of modernity and existing as anachronistic premodern minorities is problematic; Roma have long relied on the provision of certain goods and services to the majority population for their economic survival (Okely, 1983). Typically this relationship is dependent upon a distinct 'peripatetic's niche' and its ability to exploit its 'social resource' base thus implying not isolation, but a long history of interaction and exchange with majority societies (Gmelch 1986).

To turn to the second focus of existing studies of anti-Gypsyism, Racism has undoubtedly been a major factor in the stigmatisation of Roma. Racist notions are based on colonial ideologies of racial hierarchy which located the Roma in the category of 'backward/primitive' for their apparent indifference to the 'benefits' of modernity. As with other minority ethnic communities, Roma have been classified as 'dirty' (Sibley, 1994), as pollutants that are strangers in modern society (Simmel, 1971). Notwithstanding some debates on the nature of racism against Roma research on the racialised nature of anti-Gypsyism has been extensive (Acton, 2016).

We would argue however, that on its own racism only provides a partial view on the current situation of Roma. Their historically vulnerable position has worsened in recent decades as a result of the wide reaching economic, social and political changes brought about by contemporary neoliberalism and globalisation. Within this environment, the endless pursuit of profit and associated consumerism has resulted in social harms that have also impacted on other minority communities and large sections of the working class (Reiner, 2007; Winlow et at, 2017). From a UK perspective, in terms of employment these changes have rendered many traditional forms of work carried out by Gypsies and Travellers redundant. Also, labour driven migration and increased mobility of the wider workforce throughout Europe has intensified competition for the seasonal agricultural work those communities had long performed. Additionally, many of the goods and services that mobile Gypsies and Travellers in the UK had once provided have become virtually obsolete, and travelling lifestyles are increasingly difficult to maintain due to anti-nomadic legislation and policies (Belton, 2005; James, 2006, 2014). Similar forms of exclusionary work patterns have impacted on the seasonal employment of Roma in the West of Europe, while in the East the employment, housing and healthcare provided to Roma within communist regimes has subsequently been lost (Cahn and Vermeersch, 2007, Raihman, 2007). These Roma have suffered chronic levels of economic exclusion and labour market discrimination that has served to push them 
to migrate to the West, where they compete with other migrants for seasonal work that ironically may have previously been performed by their indigenous counterparts. Vilified by western Europe as economic migrants or 'benefit tourists' and by the east as harbingers of negative western perceptions about the 'primitive' eastern and central regions of Europe, Roma are placed in an untenable position (Acton, 2010).

In addition to and associated with shifting patterns of employment, Roma have been spatially excluded within rural and urban environments. As land and property have become more valuable in western Europe and as wealth has been gained from its sale and use, Roma have been removed from it (Morris and Clements, 2002). Cities have gentrified and rural areas been appropriated by the middle classes as their idyllic playground. Despite the fact that research has evidenced the illusive nature of Roma ethnicity (Acton, 2016), a romantic myth of what constitutes legitimate ethnic 'Gypsy' identity has burgeoned while the reality of impoverishment and marginalisation for Roma is their lived reality (Sibley, 1994; Somersan and KircaSchroeder, 2007). Holloway (2005:360) found in her research in the UK that positive public perceptions of Roma were particularly associated with dark skin colour, rather than the cultural markers of their contemporary identity. Indeed, she found that those Roma who did not conform to romantic stereotypes of their 'traditional' characteristics, including having darker skin colour and living in horse-drawn waggons, were regarded as criminals and 'hangers on'. The reduction of identity to ethnicity evidenced here has served to essentialise Roma and produced an inverted racism wherein their whiteness denotes inferiority. A double bind therefore occurs: dark skinned Roma migrants to the UK experience prejudice such as the negative press coverage that focused on their 'foreign' and alien customs, such as childhood engagement, bride auctions and child marriage, whereas indigenous Gypsies and Travellers are often portrayed as a sub-element of the white British underclass (Smith, 2016). Interestingly then, the prejudice is meted out against Roma on the basis of their cultural markers of poverty and exclusion as well as their ethnicity.

Above we have identified some of the economic, social and political forces that have eroded the mobility, autonomy and self-reliance that have characterised Roma communities throughout history, pushing many into the disenfranchised end of the working class. In contemporary society we would suggest that it is necessary to acknowledge that once there they have been subject to the same neoliberal policies of deregulation and privatisation that have channelled large swathes of the working class, including other minority ethnic communities, into the precariat: those groups whose lives are defined by precariousness and insecurity, especially in relation to work (Standing, 2014). As the precariat experience this 'massive structural violence from above' (Wacquant, 2008: 24), so they have been consigned to 'neighbourhoods of exile'. Such neighbourhoods are marked by 'territorial stigma' and are far removed spatially and socially from the professional middle classes who write about these trends from a distance. They therefore do not necessarily identify and thus obscure to many observers the underlying structural forces at play here. It is necessary to 
address the spatial outcome of these trends that is an increasing geographic concentration of those, including the Roma that lack or reject the forms of 'capital' necessary for social mobility in globalised, neoliberal and post-industrial societies. Further, additional to the exclusion of those within the precariat, as a consequence of shared residential space and competition for the same pool of work Standing (2014:42) notes, 'Tensions within the precariat are setting people against each other, preventing them from recognising that the social and economic structure is producing their common set of vulnerabilities'. Social tensions therefore arise within and beyond the precariat that can be seen in the rise in hate crimes throughout Europe (OSCE, 2015). These hate crimes have commonly been attributed to an increase of far-right groups and ideology rather than neoliberal capitalism that has actually created the conditions within which hate festers (Winlow et al, 2017) or is 'enabled', as noted by Chakraborti and Hardy earlier in this special edition.

Roma experiences of marginalisation therefore are augmented by their economic and social vulnerability and exacerbated by racist and anti-nomadic policies such as ethnic profiling, segregation and forced expulsions (McGarry, 2011). The capacity of EU institutional and policy mechanisms to address the deep rooted social exclusion of many Roma across the EU through focusing on 'anti-Gypsyism' will be considered next.

\section{EU Policy and the Hate Crime Agenda}

Roma inclusion has been a central plank of EU equalities policy, particularly since post-communist transition. Specific recognition of Roma victimisation in central and eastern Europe led to the 2011 EU Framework for National Roma Integration Strategies. This involved scrutiny of existing and prospective EU member states monitoring of 'anti-Gypsyism' and securing civil and human rights as a condition of joining the EU.

Victimisation on the basis of identity has been classified as 'hate crime' and 'hate speech' in academic and policy environments in recent years, following policy examples from the USA (Perry, 2001). The EU monitors hate crimes specifically (European Union Minorities and Discrimination Survey, 2012, OSCE, 2015, 2012, 2011) while EU funded projects have examined the impact of hate speech against Roma communities (PRISM, 2015). How far these measures have improved the lot of Roma communities though is open to question. In the run up to EU accession some countries simply minimised recorded hate against Roma to that end (Sobotka and Vermeersch, 2012) and it is evident that across Europe Roma communities continue to be used as scapegoats by the political right that has identified them as the fearful 'other' (Stewart, 2012; James, 2015).

In the face of an upswing in anti-Gypsy sentiment across much of central and eastern Europe post 1989 combined with EU expansion, as noted above there has been a westward migration of Roma to the UK and Western Europe (Mawby, 2009). 
Once there Roma have been used by anti-EU parties to symbolise all that is wrong with the EU principle of freedom of movement. Media and politically driven moral panics surrounding a potential influx of criminally inclined Roma 'welfare tourists' from Romania and Bulgaria were a key element in stoking up fears over large scale migration in the run up to the UK EU referendum vote (Smith, 2016). Indeed, we recognise that such fear mongering was partly responsible for the rise in hate crimes during that period (Sharman and Jones, 2017).

Commentators such as Morris (2016) have argued that Brexit may represent a dire environment for Roma who will be beyond the reach of the security provided by EU inclusion policies that frame, fund and support national strategies for Roma integration (EU 2011). However, the cursory response of the UK government and other member states to the EU Framework indicates the low priority governments attach to complying with these requirements. The failure of states to act has been described by Perry (2001) as a form of collusion with those who commit hate crime, and the lack of international statute to address states failure to conform to EU policy has resulted in local intransigence, such as the failure of the state of Ireland to legislate against hate crime (Haynes and Schweppe, 2016). Burns (2016) research shows that there has also been a lack of successful cases sent to the European Court of Human Rights wherein state-tolerated and state-sponsored violence against Roma has been claimed. This may suggest that there were no cases to answer, though this seems unlikely given the wealth of evidence of such activity gathered by civil society and the academy (for example see: James, 2007; Clough Marinaro, 2009; Kesetovic, 2009; Szikinger, 2010; Bumbu, 2012; Buckova, 2012). It perhaps purports instead to the incapacity of the European Court to serve the justice needs of the precariat more widely and Roma more specifically.

EU policy on Roma focuses on the necessity to tackle racism. However, this has served to remove the Roma experience from a wider discourse on poverty and exclusion such as that suggested above. The advance of identity politics and the assertion of 'difference' between the majority and various ethnic minorities since the 1970 s has on one hand, been politically beneficial and brought a measure of social and political inclusion for minority group members. On the other hand, as Alleyne (2002:609) notes, this approach can 'totalize people into 'communities' and serve to reinforce historically and theoretically untenable notions of difference between things unreflexively and ahistorically imagined as 'cultures', 'communities', 'ethnic groups' and 'races'". This makes it an effective strategy for governing as it drives conflict both between and within different social and ethnic groups. From this perspective social and economic inequalities are articulated as ethnically and culturally based through its preoccupation with what divides people and downplaying the underlying economic and political processes that are driving those inequalities and which impact on all social groups. Multiculturalism, as Winlow et al (2017) note, therefore offers a positive cultural programme alongside a brutally negative economic programme 
characterised by ferocious economic competition and does not serve the needs of all, let alone the needs of the few.

EU policy and associated practice has disconnected Roma from the rest of society by essentialising their identity (Surdu and Kovats, 2015). This has served the purpose of identifying Roma as a vulnerable group, alongside other minorities that are 'hated' and victimised on that basis. Thus, hate crime policy and practice has set out with the laudable aim of protecting the vulnerable in society (Chakraborti and Garland, 2012). However, the hate crime agenda has not sufficiently embraced the question of why such crimes occur in late modernity. Although, as one reviewer of this paper noted, EU policy may not intend to tackle the causes of hate, it has certainly asserted that membership should enable equalities and challenge prejudice (EU, 1997). Perry (2003) has noted the power of hate crime to serve as a message to the vulnerable not to challenge the hegemonic order but it is the lack of recognition of neo-liberalism's impact on the vulnerable in society, of which Roma are a part, which has resulted in policies that serve the interests of the status quo. The beneficiaries of identity politics then, from which the hate crime agenda is derived, have subsequently largely been self-appointed community leaders working in unison with their well-educated, middle class advocates and 'experts' whose existence and social privilege is contingent on the continuing exclusion and stigmatisation of those groups they represent. Civil society organisations can be insular, failing to represent Roma voices (Okely, 2014; Acton and Ryder, 2015) while Valeriu (2013:np) lambasts the EU Roma agenda for its failure to truly engage with Roma and its,
"Useless and very expensive conferences, bombastic empty speeches, copy and paste type newspeak reports, training for the sake of spending money and poorly thought projects focused on absorption of money rather than addressing the problems did nothing but delegitimised the European Commission and Member States efforts and weakened even further the already weak Roma civil society."

A hierarchy of need, vulnerability and victimisation has been created, reasserting existing racisms by setting up who are legitimate victims and who are not (Chakraborti and Garland, 2012). This in turn has encouraged right-wing extremists to utilise that hierarchy and identify 'others' as scapegoats for society's ills thus diverting attention from exclusionary processes experienced in common with many working class and minority ethnic people. Identity politics and the EU policies borne from them have divided the disenfranchised, rather than united them. Despite its aims to challenge powerful elites, the hate crime agenda has fed this process by embracing multiculturalism without an accompanying critique of the political economy of neoliberalism (as was originally denoted by civil rights movements in the 1960s). The capacity of contemporary research, policy and practice to be blindsided 
by the 'logic' of neoliberalism evidences its dispersed power and ability to shape even the most inclusive of agendas (Fisher, 2009).

We will now go on to consider the social harm caused by the hate crime agenda's narrow and partial focus and argue for the need to recognise discrimination against Roma as part of the spectrum of hate in late modernity.

\section{Discrimination as Systemic Violence}

The research and policy focus on Roma experiences of 'hate crime' in itself is problematic. Hate crime legislation and policy distinguishes between hate crimes and hate incidents but does not incorporate discrimination motivated by hate. Research evidence shows that discrimination is as harmful to Roma communities as hate crimes, if not more (James, 2011). It is therefore the bias-motivation, rather than the action, that counts from the Roma perspective. This has been misinterpreted by hate crime scholars and policy makers as necessitating legislation and policy against bias-motivated crimes, rather than a consideration of where that motivation comes from and how to address it. The populist punitive response to hate crime is driven by the horrific nature of hate victimisation, including murder, arson, physical assaults and criminal damage against Roma throughout Europe (see James, 2015 for a review of the literature). The insecurity created by these events for the individuals affected and their wider communities can be catastrophic (Bowling, 1999) and push them further in to the disenfranchised spaces of the precariat. However, as Reiner (2007) notes, the culture of neoliberalism creates an anomic society that erodes moral values and social solidarity. Consequently punitive law and order strategies do not impact on the perpetrators of hate, whose prejudice is borne of fear and insecurity that is exacerbated by those very measures and is reflected in media discourse and state discrimination as discussed below.

Despite the extensive impact of hate crimes on communities, it is the discrimination they experience that really troubles Roma and impacts directly on their daily lives (James, 2015). As such it should be acknowledged as the central aspect of their experience of exclusion (Phillips and Bowling, 2008). Discrimination against Roma exists on multiple levels: exclusion from health and education services, from physical spaces and from civil participation. Across the EU around $90 \%$ of Roma live in households below national poverty lines and less than one in three are in paid work (FRA, 2011). Further, they have some of the worst outcomes in terms of health, education and welfare throughout Europe (EPHA, 2014).

Hate crime policies that record EU wide levels of bias-motivated offending constitute recording of what Zizek (2008:1) refers to as 'subjective violence' experienced by Roma in society, where a perpetrator and victim can easily be distinguished. By contrast the discrimination they suffer as a consequence of the neoliberal political order is 'systemic violence' that is not measured or acknowledged. The precarious position of Roma as victims of discrimination has been evidenced by reports and 
research as noted above and significantly by the UN Special Rapporteur on minority issues who acknowledged "the deeply embedded social and structural discrimination Roma face worldwide" (2015: 5). However, the minority rights approach to resolving that discrimination simply reasserts cultural political discourse that uses racism and anti-nomadism as the tools to deconstruct the problem.

The minority rights perspective produces policy interventions to promote social inclusion that start from a 'deficit model'. Roma's social and economic exclusion are treated as a matter of individual competency and a lack of skills due to a cultural orientation that places a low value on social mobility or self-improvement. At the same time racism and anti-nomadism are seen as products of individual attitudes that can be rectified through education and 'cultural awareness' training. Silva (2014) argues that in this regard the current politics of 'integration' in the EU constitutes a strategy of denial that depoliticises and therefore shuts down discussion of the political and legal structures which protect privilege and govern minorities.

The discrimination experienced by Roma is exacerbated by racism and antinomadism that structures their lived experience. However, it is determined by the systemic violence that manifests in their societal position as one part of the precariat - their insecurity in a global capitalist system based on individualism and consumption within which 'non-productive' elements like Roma are redundant and fair game for repressive and discriminatory policies and treatment. This social structural location in turn reproduces the systemic violence imposed upon it, replicating the hierarchies of wider society and pitching battles within different elements of the working classes along fissures of race, gender, competition for work, affordable accommodation and use of limited spaces. The hate that manifests as subjective violence within the precariat is described by Winlow et al (2017:8) as 'inarticulate anger' which is directed at the fearful other, who are likely victims of the same socioeconomic and political processes themselves. We would argue therefore that EU policy and practice, including the hate crime agenda, should challenge the divisive capacity of single issue politics and propose a collective approach to challenging systemic violence such as discrimination.

\section{Conclusion}

In this paper we have set out an initial critique of existing scholarly explanations for anti-Gypsyism that utilise anti-nomadism and racism to explain the marginalised position of Roma throughout Europe. Such explanations have been embedded into EU policy and practice and specifically inform the hate crime agenda. We have proposed that the EU response to anti-Gypsyism is based on a divisive approach that separates the experiences of different marginalised communities despite their commonalities as part of the precariat. The paper has therefore argued that the EU has failed to acknowledge or provide mechanisms to address either bias-motivated crimes committed against Roma or discrimination against Roma. Our analysis has utilised Zizec's (2008) concept of violence in order to distinguish between the 
subjective violence experienced by Roma as hate crime, and the systemic violence experienced by Roma as discrimination. The EU hate crime agenda has provided some measures of hate victimisation (though as noted above these measures are themselves problematic), but it has not acknowledged the potential cause of hate crime. We suggest here that hate crime is a social harm caused by the neoliberal political economy of late modernity that is itself systemically violent.

Callinicos (2015:4) argues that rather than representing the transcendence of nationalism, the EU "has provided a framework in which the larger European capitalisms could pursue their interests" and that "for the past 30 years... has functioned as an engine promoting neoliberalism both within and beyond its borders". Roma do not fit within this system because their cultures are based on sustainable and communal lifestyles rather than on the fleeting individualised cultures of consumer capitalism. At best then, EU policies have resulted in recognition of the subjective violence committed against Roma. The capacity of this to result in changed systems and attitudes is questionable while the systemic nature of that hate remains neglected and not addressed.

Laclau and Mouffe (1985) propose a broad based democratic coalition between migrant, black, women's, working class groups and new social movements and we would commend a more critical approach from hate crime scholars to evidence the need for changed process and practice. It is clear that post-Brexit a more inclusive approach must recognise that our most fundamental problems as a society are economic inequality and exclusion rather than a lack of tolerance and cultural acceptance (Winlow et al, 2017). Indeed it is economic injustice and exclusion that is fuelling intolerance and divisions along ethnic/cultural lines. Such a reorientation of priorities is needed to both transcend the narrow and sectional cultural politics and to challenge the rise of right wing populism or the potential for growing social divisions and hate crime remains high. Overall then we would suggest that the EU system currently in place has not sufficiently benefitted Roma communities and as such the UK's exit from the EU is unlikely to have a significant impact on Roma experiences of daily life in the UK. This does not mean to say that transnational approaches to tackling social exclusion should not be embraced. Rather, that they require a consideration of the systemically violent nature of contemporary neoliberal capitalism in order to develop strategies for change.

\section{References}

Acton, T. (2010) 'Theorising Mobility: Migration, nomadism, and the social reconstruction of ethnicity'. In: Romani Mobilities in Europe Conference. University of Oxford.

Acton, T. (2016) Scientific racism, popular racism and the discourse of the Gypsy Lore Society. Ethnic and Racial Studies. 39(7): 1187-1204. 
Acton, T. and Ryder, A. (2015) The Gypsy Council - Approaching 50 years of Struggle. Roma Rights: Journal of the European Roma Rights Centre. 2: 2015.

Alleyne, B. (2002) 'An idea of a community and its discontents: towards a more reflexive sense of belonging in multicultural Britain' Ethnic and Racial Studies, Vol. 25, No. 4, pp. 607-627.

Beier, A. L. (1985) Masterless men: the vagrancy problem in England 1560-1640, New York: Methueun

Belton, B. A (2005) Gypsy and Traveller ethnicity: the social generation of an ethnic phenomenon, London: Routledge.

Bowling, B. (1999) Violent Racism: Victimisation, Policing and Social Context, Oxford: Oxford University Press.

Buckova, A. (2012) 'Antigypsyism in Slovakia'. In: Kyuchokov, H. (Ed) New Faces of Antigypsyism in Modern Europe. Prague: Decade Trust Fund.

Bumbu, G. (2012) 'Antigypsyism in Romania'. In: Kyuchokov, H. (Ed) New Faces of Antigypsyism in Modern Europe. Prague: Decade Trust Fund.

Burns, N. (2016) An Analysis of the Cases of Anti-Roma Violence before the European Court of Human Rights. In: International Network of Hate Studies Biennial Conference, University of Limerick, Ireland. 24-26 May 2016.

Cahn, C. and Vermeersch, P. (2007) 'The group expulsion of Slovak Roma by the Belgian government: A case study of the treatment of Romani refugees in western countries'. Cambridge Review of International Affairs, 13(2): 71-82.

Callinocos, A. (2015) 'The internationalist case against the European Union', International Socialism, Issue 148. http://isj.org.uk/the-internationalist-case-againstthe-european-union/

Chakraborti, N. and Garland, J. (2012) Reconceptualizing hate crime victimization through the lens of vulnerability and 'difference'. Theoretical Criminology. 16(4): 499514.

Clough Marinaro, I. (2009) 'Between Surveillance and Exile: Biopolitics and the Roma in Italy'. Bulletin of Italian Politics, 1(2): 265-287.

EU (1997) European Union Anti-Discrimination Policy: from equal opportunities between women and men to combating racism. Available at:

http://www.europarl.europa.eu/workingpapers/libe/102/default_en.htm\#summary. (Accessed on: 07/08/17)

EU (2011) An EU Framework for National Roma Integration Strategies up to 2020. European Commission. 
European Public Health Alliance (EPHA) (2014) Roma Health in Europe, available at: http://epha.org/IMG/pdf/FULL EPHA Position paper on Roma Health-FINAL-2.pdf European Union Minorities and Discrimination Survey, 2012,

Fisher, M. (2009) Capitalist Realism: Is there no alternative? Zero Books.

Fraser, A. (1992) The Gypsies, Oxford: Blackwell.

Fundamental Rights Agency (2011) Poverty and employment: the situation of Roma in 11 EU member states. Vienna: EU Agency for Fundamental Rights.

Gmeich, S. B. (1986) 'Groups that Don't Want In: Gypsies and other Artisan, Trader and Entertainer Minorities', Annual Review of Anthropology, Vol. 15, pp. 307-330.

Halfacree,K. (1996) Out of Place in the Country: Travellers and the "Rural Idyll". Antipode. 28(1):42-72.

Haynes, A. and Schweppe, J. (2016). Internationalizing Hate Crime and the Problem of the Intractable State: The Case of Ireland. In: Schweppe, J. and Walters, M. (Eds) The Golbalization of Hate: Internationalizing Hate Crime? Oxford: Oxford University Press.

Holloway, S.L. (2005) 'Articulating otherness? White Rural Residents Talk about Gypsy-Travellers', Transactions of the Institute of British Geographers, 30 (3): 351367.

James, Z. (2006) Policing Space: Managing New Travellers in England. British Journal of Criminology. 46(3): 470-485.

James, Z. (2007) Policing Marginal Spaces: Controlling Gypsies and Travellers. Criminology and Criminal Justice: An International Journal. 7 (4): 367-389.

James, Z. (2011) 'Gypsies and Travellers in the Countryside: managing a risky population', in Yarwood, R. and Mawby, R.I. (eds.) Constable Countryside? Policing, Governance and Rurality, Aldershot: Ashgate.

James, Z. (2014) Offenders or Victims?: An exploration of Gypsies and Travellers as a policing paradox. In: Phillips, C. and Webster, C. (eds) New Directions in Race, Ethnicity and Crime. Abingdon: Routledge.

James, Z. (2015) Hate Crimes Against Gypsies, Travellers and Roma in Europe. In: Hall, N., Corb, A., Giannasi, P. and Grieve, J. (Eds) The Routledge International Handbook on Hate Crime. Abingdon: Routledge.

Kabachnik, P. (2009) 'To choose, fix or ignore culture? The cultural politics of Gypsy and Traveller mobility in England', Social and Cultural Geography, 10 (4): 461-479.

Karner, C. (2004) Theorising Power and Resistance among 'Travellers'. Social Semiotics. 14(3): 249-271 
Kenrick, D. and Puxon, G. (1972) The Destiny of Europe's Gypsies. New York: Basic Books, Inc.

Kesetovic, Z. (2009) 'Understanding diversity in policing: Serbian perspectives'. Policing: An International Journal of Police Strategies and Management, 32(3): 431 445.

Laclau, E. and Mouffe, C. (1985) Hegemony and Socialist Strategy.Verso.

Liegeois, J-P. (1994) Roma, Gypsies, Travellers. Strasbourg: Council of Europe.

Kostadinova, G. (2011) 'Minority Rights as a Normative Framework for Addressing the Situation of Roma in Europe'. Oxford Development Studies, 39(02): 163-183.

MacLaughlin, J. (1999) "Nation-Building, Social Closure and Anti-Traveller Racism in Ireland", Sociology, Vol. 33, No. 1.

Mawby, R.C. and Gisby, W. (2009) Crime, Media and Moral Panic in an Expanding European Union. The Howard Journal. 48(1): 37-51.

Mayall, D. (1988) Gypsy-travellers in nineteenth century society, Cambridge:

Cambridge University Press.

Mc Garry, A. (2011) 'The dilemma of the European Union's Roma policy', Critical Social Policy, 32(1): 126-136.

McVeigh, R. (1997) Theorising sedentarism: the roots of anti-nomadism, In: Acton, T. (ed) Gypsy politics and traveller identity, pp. 7-25. Hatfield: University of Hertfordshire Press.

Morris, M. (2016) Roma Communities and Brexit. London: Institute for Public Policy Research.

Morris, R. and Clements, L. (2002) At What Cost? The Economics of Gypsy and Traveller Encampments. Bristol: The Policy Press.

Okely, J. (1983) The Traveller-Gypsies, Cambridge: Cambridge University Press.

Okely, J. (2014) Recycled (mis)representations: Gypsies, Travellers or Roma treated as objects, rarely subjects. People, Place and Policy (8)1: 65-85.

OSCE (2011) Hate Crimes in the OSCE Region: Incidents and Responses. Annual Report for 2010. Warsaw: OSCE ODIHR.

OSCE (2012) Hate Crimes in the OSCE Region: Incidents and Responses. Annual Report for 2011. Warsaw: OSCE ODIHR.

OSCE (2015) Hate Crimes in the OSCE Region: Incidents and Responses. Annual Report for 2014. Warsaw: OSCE ODIHR. 
Perry, B. (2001) In the Name of Hate: Understanding Hate Crimes. New York: Routledge.

Perry, B. (2003). Hate and Bias Crime. A reader. New York, USA, and London, UK: Routledge.

Phillips, C. and Bowling, B. (2008) Racism, ethnicity and criminology: Developing minority perspectives. In: Spalek, B. (Ed) Ethnicity and Crime: A Reader. Maidenhead: McGraw Hill.PRISM, 2015

Raihman, L. (2007) ‘Between Litigation and Freedom of Speech'. Roma Rights Quarterly, 3/2007: 105-108. Reiner (2007

Reiner, R. (2007) Neoliberalism, crime and justice. In: Roberts, R. and McMahon, W. Social Justice and Criminal Justice. London: Centre for Crime and Justice Studies.

Ryder, A. (2011) Big Bang Localism and Gypsies and Travellers. Cornivus Journal of Sociology and Social Policy. 2(2): 27-45.

Sharman, J. and Jones, I. (2017) 'Hate crimes rise by up to 100 per cent across England and Wales, figures reveal.' Independent. Available at:

http://www.independent.co.uk/news/uk/home-news/brexit-vote-hate-crime-rise-100per-cent-england-wales-police-figures-new-racism-eu-a7580516.html. (Accessed on: 07/08/17)

Sibley, D. (1994) The Sin of Transgression. Area. 26(3):300-303.

Somersan, S. and Kirca-Schroeder, S.(2007) 'Resisting Eviction: Sulukule Roma in Search of Right to Space and Place'. The Anthropology of East Europe Review, 25(2): 96-107.

Silva, R. M. (2014) 'Civilising the Roma? The depoliticisation of (anti-) racism within the politics of 'integration", Identities: Global Studies in Culture and Power, 22(1): 5370.

Simmel, G. (1971) On individuality and social forms: selected writings of George Simmel. Chicago: University of Chicago Press.

Smith, D. and Greenfields, M. (2013) Gypsies and Travellers in Housing: The decline of Nomadism. Bristol: Policy Press.

Smith, D. (2016) The political context of migration in the UK: the case of Roma Gypsies. In: Zakaria, N. Abdul-Talib, A. and Osman, N. (2016) (eds.) Handbook of Research on the Impacts of International Business and Political Affairs on the Global Economy, Pennsylvania, USA: IGI Global. 
Sobotka, E. and Vermeersch, P. (2012) 'Governing Human Rights and Roma Inclusion: Can the EU be a Catalyst for Local Social Change?'. Human Rights Quarterly, 34 (3): 800-822.

Standing, Guy (2014). A Precariat Charter: from denizens to citizens. London New York: Bloomsbury Academic.

Stewart, M. S. (2012) 'New Forms of Anti-Gypsy Politics: A problem for Europe'. In: Stewart, M.S. (Ed) The Gypsy Menace. London: Hurst and Co.

Surdu, M. and Kovats, M. (2015) Roma Identity as an Expert-Political Construction. Social Inclusion. 3(5): 5-18

Szikinger, I. (2010) 'The Roma in Hungary'. Policing and Society, 10(1): 91-106.

UN Special Rapporteur (2015) Report of the Special Rapporteur on minority issues: Comprehensive study of the human rights situation of Roma worldwide, with a particular focus omn the phenomenon of anti-Gypsyism. United Nations.

Valeriu, N. (2013) 'Between a rock and a hard place - the new Commission and the social inclusion of Roma'. Available at:

http://ednomagazine.com/en/oppinions/between-a-rock-and-a-hard-place-the-newcommission-and-the-social-inclusion-of-roma. Accessed on: 16/05/17

Wacquant, I. (2008) Urban outcasts: a comparative sociology of advanced marginality, Cambridge: Polity

Winlow, S., Hall, S. and Treadwell, J. (2017) The Rise of the Right: English nationalism and the transformation of working class politics. Bristol: Policy Press.

Zizek, S. (2008) Violence. New York: Picador. 